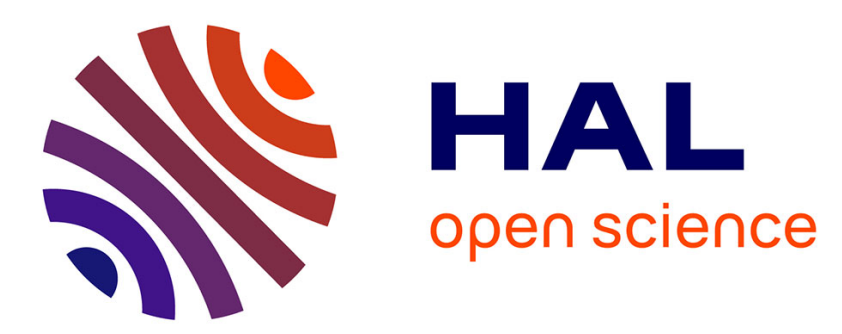

\title{
The Structural Characteristics of the Dispersed State of $\mathrm{CdO} / \gamma-\mathrm{Al} 2 \mathrm{O} 3$ System
}

\author{
X. Cai, Zhuoxiang Ren, Z. Liu, Y. Xie, T. Hu, Ya. Xie
}

\section{To cite this version:}

X. Cai, Zhuoxiang Ren, Z. Liu, Y. Xie, T. Hu, et al.. The Structural Characteristics of the Dispersed State of CdO/ $\gamma$-Al2O3 System. Journal de Physique IV Proceedings, 1997, 7 (C2), pp.C2-901-C2-902. 10.1051/jp4:1997272 . jpa-00255355

\section{HAL Id: jpa-00255355 https://hal.science/jpa-00255355}

Submitted on 1 Jan 1997

HAL is a multi-disciplinary open access archive for the deposit and dissemination of scientific research documents, whether they are published or not. The documents may come from teaching and research institutions in France or abroad, or from public or private research centers.
L'archive ouverte pluridisciplinaire HAL, est destinée au dépôt et à la diffusion de documents scientifiques de niveau recherche, publiés ou non, émanant des établissements d'enseignement et de recherche français ou étrangers, des laboratoires publics ou privés. 


\title{
The Structural Characteristics of the Dispersed State of $\mathrm{CdO} / \gamma-\mathrm{Al}_{2} \mathrm{O}_{3}$ System
}

\author{
X. Cai, Z. Ren, Z. Liu, Y. Xie, T. Hu and Ya. Xie \\ Department of Chemistry, Peking University, Beijing 100871, P.R. China \\ * Institute of High Energy Physics, Beijing 100039, P.R. China
}

\begin{abstract}
A comparison between the FT functions of XAFS of $\mathrm{CdO} / \gamma-\mathrm{Al}_{2} \mathrm{O}_{3}$ and $\mathrm{NiO} / \gamma-\mathrm{Al}_{2} \mathrm{O}_{3}$ systems was carried out. The results show that their situations are very different. For the former, there is no $\mathrm{Cd}-\mathrm{Cd}$ coordination peak corresponding to the first $\mathrm{Cd}-\mathrm{Cd}$ coordination shell in the crystalline $\mathrm{CdO}$ and the coordination numbers of the first $\mathrm{Cd}-\mathrm{O}$ shell decrease to 3.0. But after NiO disperses, Ni-O coordination numbers just decrease a little. The coordination numbers of the Ni-Ni shell corresponding to the first, even the farther Ni-Ni coordination shells of NiO remain partly. Maybe the differences between them are mainly due to the their different radii and the different fitness to the support.
\end{abstract}

\section{Introduction}

What are the main factors to the structure of dispersed phase? It is a problem concerned by both theoretical and practical field. Here we make a comparison of dispersed states of $\mathrm{CdO}$ and $\mathrm{NiO}$ in order to investigate the effect of the radii of ions in oxides. The structure of dispersed $\mathrm{NiO}$ has been studied widely[1], so here we focus in the structure of dispersed $\mathrm{CdO}$. CdO has the same structure type, but $\mathrm{Cd}^{2+}$ has different cation radius from $\mathrm{Ni}^{2+}$.

\section{Results and Discussion}

$\mathrm{CdO} / \gamma-\mathrm{Al}_{2} \mathrm{O}_{3}$ system was prepared by impregnation and calcination at $773 \mathrm{~K}$ for 8 hours. The specific surface area of $\gamma-\mathrm{Al}_{2} \mathrm{O}_{3}$ is $221 \mathrm{~m}^{2} / \mathrm{g}$. The threshold (dispersion capacity) obtained by $\mathrm{XRD}$ phase quantitative analysis is $0.34 \mathrm{gCdO} / \mathrm{g} \gamma-\mathrm{Al}_{2} \mathrm{O}_{3}$ (Figure 1-A).

In the $|\mathrm{FT}|$ functions of $\chi \mathrm{k}^{3}$ for pure $\mathrm{CdO}$ and samples, only the nearest $\mathrm{Cd}-\mathrm{O}$ coordination peaks ( $\mathrm{Cd}-\mathrm{O}(1)$, corresponding to the first $\mathrm{Cd}-\mathrm{O}$ coordination shell of $\mathrm{CdO}$ ) appear and the coordination peaks corresponding to the first $\mathrm{Cd}-\mathrm{Cd}$ coordination shell (corresponding to $\mathrm{Cd}-\mathrm{Cd}(1)$ in crystalline $\mathrm{CdO}$ ) disappear for completely dispersed samples, in which loadings are below the threshold. Compared with pure $\mathrm{CdO}$, the peaks are keener and have less area but shift to left. The coordination numbers of $\mathrm{Cd}-\mathrm{O}$ in dispersed phase decrease to 3.0 , and the coordination distances decrease too. In the samples up the threshold, there is residual crystalline phase besides dispersed phase. Accordingly the $\mathrm{Cd}-\mathrm{O}$ and $\mathrm{Cd}-$ $\mathrm{Cd}$ coordination peaks of crystalline $\mathrm{CdO}$ can be found. The area of $\mathrm{Cd}-\mathrm{O}(\mathrm{l})$ peaks, especially, of all Cd-Cd peaks and their apparent coordination numbers increase with the increase of CdO loadings (shown in Figure 1-B). Apparently, it is due to the change of fraction of crystalline $\mathrm{CdO}$ in the samples.

Fourier filter was carried out on $\mathrm{Cd}-\mathrm{O}(1)$ and $\mathrm{Cd}-\mathrm{Cd}(1)$ coordination peaks. The ranges are $[1.329 \sim 2.327 \AA]$ and $[2.659 \sim 3.630 \AA]$ for $\mathrm{Cd}-\mathrm{O}(1)$ and $\mathrm{Cd}-\mathrm{Cd}(1)$ respectively. The isolation of dispersed phase $[2,3]$ is according to the following formula and the results are shown in Figure 2.

For Cd-O(1) coordination shell: $[6.0(x-T h) / x]+\left[N_{\text {Cd-O(dispereed) }} T h / x\right]=N_{C d-O(\text { (spparent). }}$. or $\left(6.0-\mathrm{N}_{\text {Cd-O(apparent })}\right) \mathrm{x}=\left(6.0-\mathrm{N}_{\mathrm{Cd}-\mathrm{O} \text { (dispersed })}\right) \mathrm{Th}$. For $\mathrm{Cd}-\mathrm{Cd}$ (1) coordination shell: (12.0-

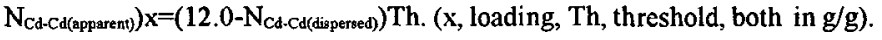

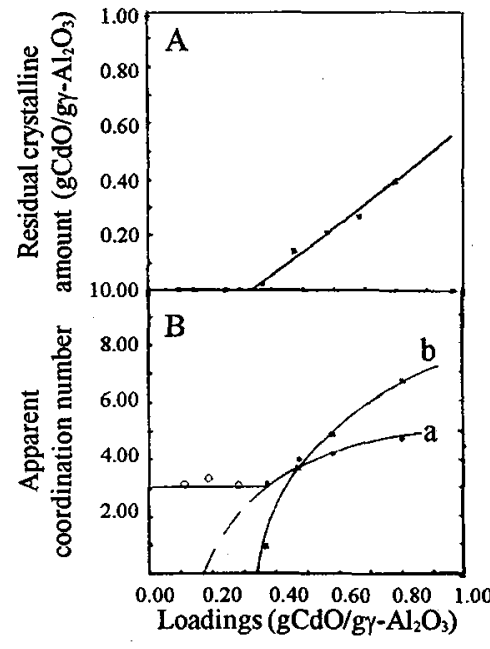

Figure 1: A. Residual crystalline amount $\sim$ loadings of $\mathrm{CdO}$ in the samples;

$\mathrm{Al}_{2} \mathrm{O}_{3}$

B. $\mathrm{N}_{\text {spprent }} \sim$ loadings of $\mathrm{CdO} / \gamma$ -

a. Cd-O coordination (corresponding to first $\mathrm{Cd}-\mathrm{O}$ coordination shell of $\mathrm{CdO}$ crystall)

b. Cd-Cd coordination (corresponding to the first $\mathrm{Cd}-\mathrm{Cd}$ coordinationn shell of $\mathrm{CdO}$ crystall)

From Figure 1, it can be seen that for the samples with loadings more than the threshold, the curves $\left(\mathrm{N}_{\mathrm{Cd}-\mathrm{O}(\mathrm{appsent})}\right.$ or $\mathrm{N}_{\mathrm{Cd}-}$ 
Ca(apparent) $\sim \mathrm{x}$ ) are just the hyperbolas. The cross points of $\mathrm{N}_{\mathrm{Cd}-\mathrm{Cd}(\text { apperent) }} \sim \mathrm{x}$ and the abscissa is $0.34 \mathrm{gCdO} / \mathrm{g} \gamma-\mathrm{Al}_{2} \mathrm{O}_{3}$. which is just equal to the threshold got from XRD. It is worthy to note also that the $\mathrm{N}_{\mathrm{Cd} \text {-O(dippersed) }}$ always is $3.0, \mathbf{N}_{\mathrm{Cd}-\mathrm{Cd} \text { (dipersed) }}$ is 0 , regardless of that it comes from direct XAFS result of perfect dispersed sample or comes from phase isolation of mixed phase samples as shown in Figure 2. The consistency demonstrates that above results are reliable. Apparently, the structure of $\mathrm{CdO} / \gamma-\mathrm{Al}_{2} \mathrm{O} 3$ is very different from $\mathrm{NiO} / \gamma-\mathrm{Al}_{2} \mathrm{O}_{3}[1]$.

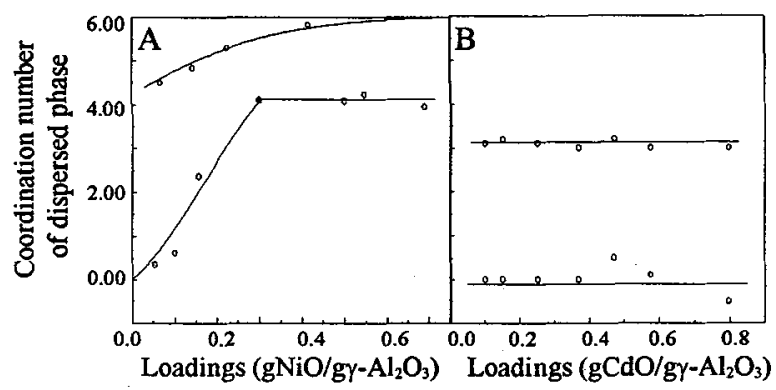

Figure 2: The actual coordination numbers of dispersed phases versus loading
$\mathrm{A}: \mathrm{NiO} / \mathrm{\gamma}-\mathrm{Al}_{2} \mathrm{O}_{3}$
$\mathrm{B}: \mathrm{CdO} / \gamma-\mathrm{Al}_{2} \mathrm{O}_{3}$
Upon: $\mathrm{Ni}-\mathrm{O}$ or $\mathrm{Cd}-\mathrm{O}$ shell corresponding to the first $\mathrm{M}-\mathrm{O}$ coordination shell in crystal;
Below: $\mathrm{Ni}-\mathrm{Ni}$ or $\mathrm{Cd}-\mathrm{Cd}$ shell corresponding to the first $\mathrm{M}-\mathrm{M}$ coordination shell in crystal.

(1) Their coordination polyhedra are different. In the dispersed phase, Ni-O coordination numbers just decrease a little, most $\mathrm{Ni}^{2+}$ ions remain octahedra coordination mode. In the dispersed phase of $\mathrm{CdO}$ on $\gamma-\mathrm{Al}_{2} \mathrm{O}_{3}$ surface, the coordination numbers of $\mathrm{Cd}-\mathrm{O}(1)$ reduce to 3.0 from 6 in crystalline phase and doesn't change with loadings below or above threshold. The coordination distances also decrease about $0.08 \AA$. Although it can not be excluded that there is the probability of several coordination modes, it is in certain that $\mathrm{Cd}^{2+}$ in dispersed phase tends to coordinate to fewer $\mathrm{O}$ atoms with shorter distance.

(2) Below the threshold, $\mathrm{Ni}-\mathrm{Ni}(1)$, and even $\mathrm{Ni}-\mathrm{Ni}(3)$ coordination increase with the increase of loadings till the maximum(at the threshold) which keeps about 4.0. But $\mathrm{CdO}$ in dispersed phase has no $\mathrm{Cd}-\mathrm{Cd}(1)$ coordination peaks. It may be because of very random distribution of $\mathrm{Cd}^{2+}$ in the dispersed phase.

Why these two oxides with same structure type have so marked differences when they are dispersed on same support? Apparently, it must be related to the different radii of $\mathrm{Cd}^{2+}$ and $\mathrm{Ni}^{2+}$. The parameters of cell of $\mathrm{NiO}$ are quite agreed with those of $\mathrm{Al}_{2} \mathrm{O}_{3}$. In the $\mathrm{NiO}$ or spinel, $\mathrm{Ni}-\mathrm{O}$ distance is close to $2 \AA$, which is near the $\mathrm{Al}-\mathrm{O}$ distance. So, when NiO is dispersed, $\mathrm{Ni}-\mathrm{O}$ and $\mathrm{Ni}-\mathrm{Ni}$ coordination shells can still remain very order state. But the parameters of cell of CdO $\left(4.659 \mathrm{~A}^{\prime}\right)$ is different from $\mathrm{Al}_{2} \mathrm{O}_{3}$ greatly. The coordination distance of $\mathrm{Cd}-\mathrm{O}(2.33 \AA)$ in $\mathrm{CdO}$ is much greater than that of $\mathrm{Al}-\mathrm{O}$ (octahedron, $1.95 \AA$, tetrahedron, $1.71 \AA$ ) in $\mathrm{Al}_{2} \mathrm{O}_{3}$, although it has same cell type as $\mathrm{NiO}$. So when $\mathrm{CdO}$ disperses on $\gamma-\mathrm{Al}_{2} \mathrm{O}_{3}$, it is difficult to keep order distribution and the previous coordination polyhedron.

The results indicate that the ion radius maybe an important, even a key factor to affect the structure of a dispersion state for some systems.

\section{Acknowledgements}

Thanks for the help of Lu Kunquan and Li Chenxi of Institute of Physics in China and Photon Factory in Japan.

\section{References}

[1] X.H. Cai, K. Q. Lu and Y. C. Xie et al.,Jpn.J. Appl. Phys., Voi. 32 (1993), Suppl. 32-2, 505

[2] K. Q. Lu and J. Wan, Phys. Rev. B, 1987, 35(9), 4497

[3] Cai Xiaohai et al, IX International Conference on X-Ray Absorption Fine Structure, Aug. 26-31 (1996) (To be published) 